\title{
Molecular characterisation and relative incidence of bean- and soybean-infecting begomoviruses in northwestern Argentina
}

\author{
P.E. Rodríguez-Pardina ${ }^{1}$, K. Hanada ${ }^{2}$, I.G. Laguna ${ }^{1}$, F.M. Zerbini ${ }^{3}$ \& D.A. Ducasse \\ 1 INTA - Instituto de Fitopatologia y Fisiologia Vegetal, Camino 60 Cuadras Km 5 1/2 (5119) Córdoba, Argentina \\ 2 National Agricultural Research Center, Kannondai 3-1-1,Tsukuba 305-8666, Japan \\ 3 Departamento de Fitopatologia/BIOAGRO, Universidade Federal de Viçosa, Viçosa, MG 36570-000, Brazil
}

\author{
Keywords \\ BGMV; hybridization; SiMoV; soybean \\ blistering mosaic virus; ToYSV.

\section{Correspondence \\ P.E. Rodriguez-Pardina, INTA - Instituto de Fitopatologia y Fisiologia Vegetal, Camino 60 Cuadras Km 5 1/2 (5119) Córdoba, Argentina. Email: prodriguezp@correo.inta.gov.ar}

Received: 12 April 2010; revised version accepted: 28 July 2010

doi:10.1111/j.1744-7348.2010.00441.x

\begin{abstract}
Recent studies identified three begomoviruses infecting soybean and bean crops in northwestern (NW) Argentina, bean golden mosaic virus (BGMV), a virus with high capsid protein identity with Sida mottle virus (SiMoV) and a possible new viral species (isolate A). Analysis of complete DNA-A sequences confirmed that isolate A represents a new viral species for which the authors propose the name soybean blistering mosaic virus (SbBMV), whereas the SiMoV-like virus is actually an isolate of tomato yellow spot virus (ToYSV). Molecular hybridisation-based detection of the three begomoviruses was accomplished using a general probe obtained by mixing full-length DNA-A clones of the three begomoviruses and specific probes comprising part of the common region of each viral genome. These probes were used to test samples collected in NW Argentina from 2004 through 2007. Fifty-three percent of the bean samples were infected with BGMV, 11.5\% with ToYSV and 9\% with SbBMV. For soybean samples, 33\% were infected with SbBMV and 18\% with ToYSV. BGMV was not detected in soybean. ToYSV was also detected in the wild species Abutilon theophrasti.
\end{abstract}

\section{Introduction}

Begomoviruses (genus Begomovirus, family Geminiviridae) represent major plant pathogens in tropical, subtropical and, to a more limited extent, temperate regions (Morales $\&$ Anderson, 2001). Begomoviruses are transmitted by whiteflies (Bemisia tabaci Genn.) to dicotyledonous plants (Fauquet etal., 2008). Most of the species in this genus have bipartite genomes consisting of two ssDNA molecules referred to as DNA-A and DNA-B. Genes in DNA-A encode proteins responsible for viral replication (Rep, replication-associated protein; REn, replication enhancer), regulation of gene expression (TrAP, transactivating protein) and particle encapsidation ( $\mathrm{CP}$, coat protein). Genes in DNA-B encode for two proteins (movement protein; nuclear shuttle protein) involved in cell-to-cell movement within the plant, host range and symptom modulation. A region of approximately 200 nucleotides common to both genomic components contains cis-acting signals required for DNA replication and transcription (reviewed by Rojas et al., 2005).

Common bean (Phaseolus vulgaris L.) is one of the most important crop species throughout Latin America, from Mexico to Argentina, representing a significant source of protein in the human diet (Singh, 1999). Seven begomoviruses are capable of naturally infecting common bean. Bean golden mosaic virus (BGMV) and bean golden yellow mosaic virus (BGYMV) cause bean golden mosaic in South America and Central America/Caribbean Basin, respectively (Gilbertson et al., 1991, 1993). This disease can cause up to $100 \%$ yield losses and seriously diminishes the quality of seeds (Garrido-Ramirez et al., 2000). Macroptilium mosaic Puerto Rico virus and Macroptilium yellow mosaic Florida virus, phylogenetically related to BGYMV (Idris et al., 2003), were originally detected in the common weed Macroptilium lathyroides (L.) Urb., and they also infect common bean. Bean calico mosaic virus was first reported in Sonora, Mexico, in 
1986, and phylogenetic analysis indicated that it is closely related to squash leaf curl virus E strain (Brown et al., 1999). Bean dwarf mosaic virus is widely distributed in Latin America at a relatively low incidence; however, this disease has a considerable epidemiological potential (Morales et al., 1990). Finally, tomato yellow leaf curl virus has been reported infecting common bean in Spain (Navas-Castillo et al., 1999) and in the Dominican Republic (Salati et al., 2002).

The soybean [Glycine max (L.) Merr.] is another economically important crop in Latin America, particularly in Argentina and Brazil, where it is used both for human consumption and animal feed (Vila-Aiub et al., 2008). In Latin America, seven begomoviruses have been reported in soybean. In the state of Sinaloa, Mexico, soybean plants were found to be infected with pepper golden mosaic virus (Morales et al., 2005; Mendez-Lozano et al., 2006). Cabbage leaf curl virus was reported in Colombia (Costa, 1975), and five viruses were reported in Brazil: Leonorus mosaic virus, Sida mottle virus (SiMoV) (Mello et al., 2002), BGMV, Sida micrantha mosaic virus and okra mottle virus (Fernandes et al., 2009). In all cases, no yield losses of economic relevance were associated with viral infection in spite of widespread colonisation of soybean crops by B. tabaci.

A recent study indicated that at least three begomoviruses infect bean and soybean crops in Argentina: (a) BGMV, (b) a virus with high sequence identity at the $\mathrm{N}$-terminal region of the capsid protein with SiMoV and (c) a putative novel viral species ('isolate A') (RodríguezPardina et al., 2006). The objectives of this work were to conclusively characterise isolate A and the SiMoV-like virus and to study their phylogenetic relationships with other begomoviruses. In addition, we developed molecular tools that were used to survey bean and soybean crops in Northwestern (NW) Argentina, the main beanproducing area of the country.

\section{Materials and methods}

Virus source

Two samples were selected from a collection of begomovirus-infected plants obtained previously in our laboratory: one from soybean (S13), collected in Horcones, Salta province, in 1995 and infected with isolate A, and one from bean (B4), collected in Isca Yacu, Santiago del Estero province, in 2002 and infected with the SiMoVlike begomovirus (Rodríguez-Pardina et al., 2006).

\section{Cloning and sequencing of isolate A}

Total DNA was extracted by the CTAB method (Doyle \& Doyle, 1987). Degenerate primers PALlv1978 and
PARlc496 (Rojas et al., 1993) were used to amplify a $\sim 1.2$-kpb DNA-A fragment that includes part of the CP gene, the intergenic region and part of the Rep gene. The PCR product was cloned into pBluescript II SK+ (pSK+) and sequenced. Based on the determined sequence, specific primers GMALA3 (5'-ACC TTC CAA AAA CGC TTG AC- $\left.3^{\prime}\right)$ and GMALA5 (5'-GAG TTG AGG AAG ATG AAT TT- $3^{\prime}$ ) were designed and used to amplify a $\sim 1.9$-kbp fragment corresponding to the remaining portion of the DNA-A. PCR products were cloned and sequenced as described.

Cloning and sequencing of the Sida mottle virus-like isolate

Total DNA extracted by the CTAB method was used as a template for rolling circle amplification using the TempliPhi kit (GE Healthcare) as described (InoueNagata et al., 2004). Putative full-length begomovirus components were released by cleavage with EcoRI and cloned into pSK+. A complete DNA-A component was sequenced by primer walking at Macrogen Inc. (Seoul, South Korea).

\section{Sequence comparisons and phylogenetic analysis}

The nucleotide and deduced amino acid sequences were compared with those of other begomoviruses available in GenBank (www.ncbi.nlm.nih.gov). Database searches were carried out using the Blast $n$ algorithm (Altschul et al., 1990). Multiple-sequence alignments of nucleotide and deduced amino acid sequences were performed with Clustal W (www.ebi.ac.uk/clustalw). Phylogenetic trees were generated with MEGA 4.0 (Tamura et al., 2007) using the neighbour-joining method. Tree branches were bootstrapped with 2000 replications.

\section{Development of DNA probes for virus detection} by molecular hybridisation

Two types of hybridisation probes were developed. A mixture of full-length DNA-A clones of BGMV, tomato rugose mosaic virus (ToRMV) and tomato mottle virus (ToMoV) was used as a general probe. Clones were linearised using specific restriction enzymes (HindIII for ToMoV and ToRMV and SmaI for BGMV). Virusspecific probes for BGMV, soybean blistering mosaic virus (SbBMV) and tomato yellow spot virus (ToYSV) were obtained by PCR amplification from total DNA extracted from samples infected by these viruses (B5, To25 and L1, respectively) (Rodríguez-Pardina et al., 2006), using the primer pairs B5-3 (5'-CTT CTC TCC GCT CGC-3' and 5'-CGT CAG GCT TGC TTT TG-3'; 127-bp amplicon), To25-1 (5'-CCC GCT CCC GCA AAT TG-3' and 


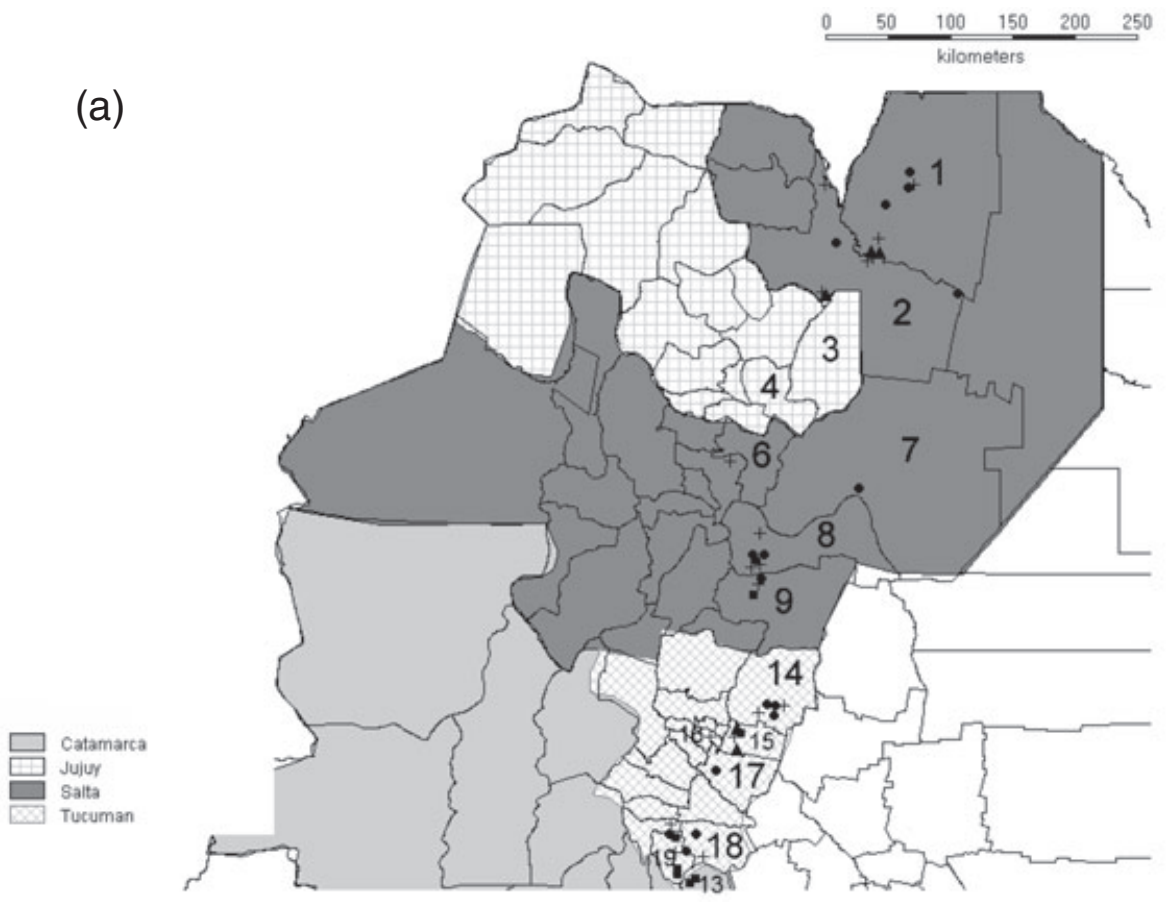

(b)

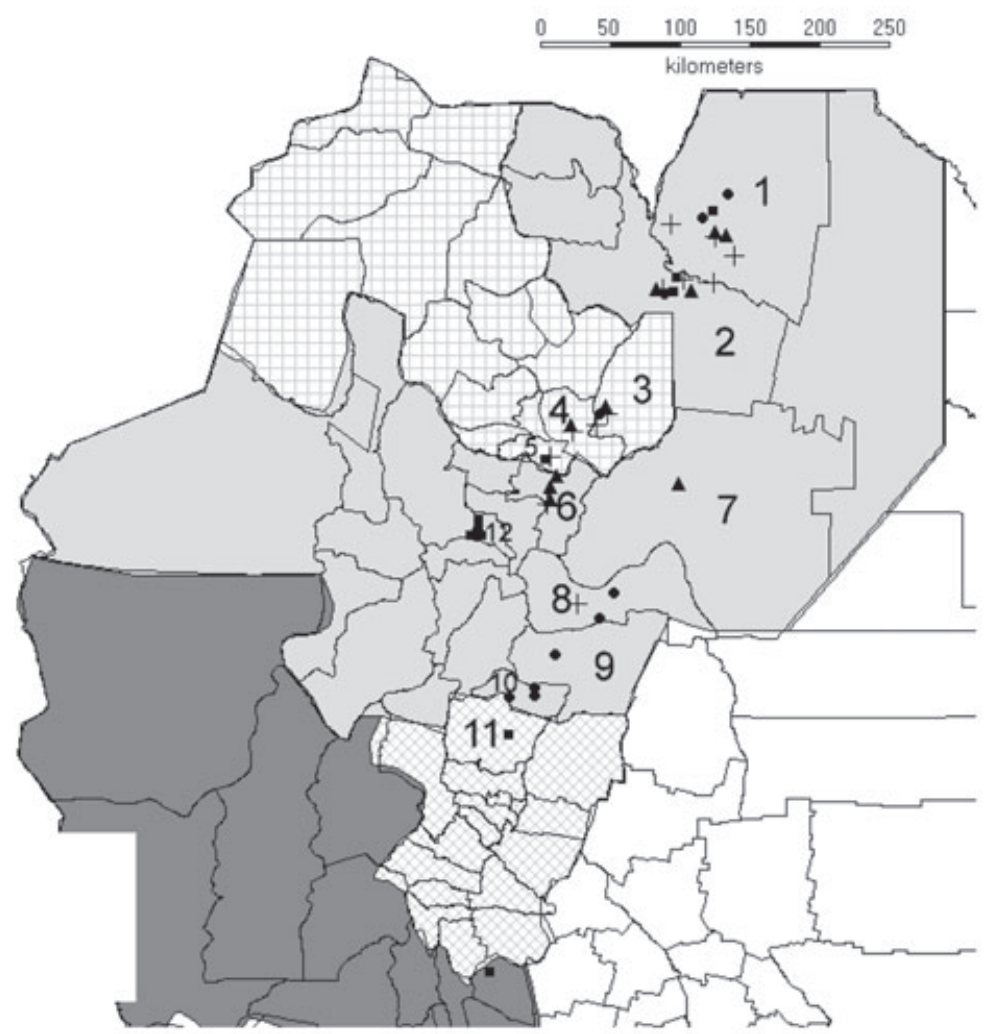

Figure 1 Locations of soybean (a) and bean (b) fields from which samples were collected. Counties: (1) San Martín; (2) Orán; (3) Santa Barbara; (4) San Pedro; (5) El Carmen; (6) General Güemes; (7) Anta; (8) Metán; (9) Rosario de La Frontera; (10) La Candelaria; (11) Trancas; (12) R. del Lerma; (13) Santa Rosa; (14) Buruyacu; (15) Cruz Alta; (16) Lules; (17) Leales; (18) Graneros; (19) La Cocha. Year of collection: $\square, 2004 ; \bullet, ~ 2005 ; \mathbf{\Lambda}, 2006 ;+, 2007$. 
Table 1 Percent sequence identities between the complete DNA-A (nucleotide sequences) and the individual ORFs (deduced amino acid sequences) of SbBMV, ToYSV-[AR] and other begomoviruses

\begin{tabular}{|c|c|c|c|c|c|c|}
\hline & \multicolumn{6}{|c|}{ Percent Identity } \\
\hline & DNA-A & $\mathrm{CP}$ & Rep & TrAP & REn & AC4 \\
\hline \multicolumn{7}{|c|}{ SbBMV versus } \\
\hline TGMV & 78 & 94 & 83 & 82 & 85 & 69 \\
\hline ToRMV & 75 & 89 & 82 & 76 & 79 & 68 \\
\hline SiMoV & 72 & 90 & 74 & 74 & 83 & 53 \\
\hline BGMV & 73 & 91 & 75 & 76 & 80 & 48 \\
\hline BDMV & 77 & 90 & 82 & 71 & 81 & 65 \\
\hline ACMV & 68 & 66 & 63 & 47 & 53 & 29 \\
\hline \multicolumn{7}{|c|}{ ToYSV-[AR] versus } \\
\hline BGMV & 78 & 93 & 76 & 73 & 83 & 46 \\
\hline SbBMV & 82 & 92 & 77 & 74 & 89 & 70 \\
\hline SiMoV & 88 & 97 & 79 & 88 & 89 & 58 \\
\hline TGMV & 81 & 90 & 82 & 71 & 84 & 72 \\
\hline TOYSV & 92 & 99.6 & 92 & 93 & 94 & 86 \\
\hline
\end{tabular}

ACMV, African cassava mosaic virus (GenBank accession number J02057) BDMV, bean dwarf mosaic virus (M88179); BGMV, bean golden mosaic virus (M88686); CP, coat protein; Rep, replication-associated protein; TrAP, trans-activating protein; REn, replication enhancer; SbBMV, soybean blistering mosaic virus; SiMoV, Sida mottle virus (AY090555); TGMV, tomato golden mosaic virus (K02029); ToRMV, tomato rugose mosaic virus (AF291705); ToYSV, tomato yellow spot virus (DQ336350).

5'-CGC AAC GAA TGG CCC-3'; 147-bp amplicon) and L1-1 (5'GGC CCA TTC ATT TTG-3' and 5'-GTA AAG AAC TTG GTC ACC-3'; 153-bp amplicon), respectively. These primers were designed based on a sequence alignment of the three viruses, and the fragments amplified correspond to the highly variable $5^{\prime}$-region of the $c p$ gene. PCRs $(25 \mu \mathrm{L})$ contained $1 \times$ Taq DNA polymerase buffer, $0.25 \mathrm{mM} \mathrm{MgCl}_{2}, 0.25 \mathrm{mM}$ of dNTP mix, $2.5 \mu \mathrm{M}$ of each primer, $2.5 \mu \mathrm{L}$ of template DNA and 0.2 units of Taq DNA polymerase (Promega, Madison, WI, USA). PCR cycle parameters were as follows: an initial denaturation at $94^{\circ} \mathrm{C}$ for $2 \mathrm{~min}$, followed by 35 cycles of denaturation at $94^{\circ} \mathrm{C}$ for $30 \mathrm{~s}$, annealing at $45^{\circ} \mathrm{C}$ (for primer pair $\mathrm{B} 5-3$ ) or $55^{\circ} \mathrm{C}$ (for primer pairs To25-1 and L1-1) for $30 \mathrm{~s}$ and extension at $72^{\circ} \mathrm{C}$ for $1 \mathrm{~min}$, with a final extension step at $72^{\circ} \mathrm{C}$ for $5 \mathrm{~min}$. All probes were labelled with digoxygenin using the DIG DNA Labelling and Detection kit (Roche Applied Sciences, Indianapolis, IN, USA), according to the manufacturer's instructions.

Probes were tested by dot-blot hybridisation. Total nucleic acids extracted by the Dellaporta protocol (Dellaporta et al., 1983) were blotted onto nylon membranes by spotting $50 \mu \mathrm{L}$ in vacuo using a Bio-Dot apparatus (Bio-Rad, Hercules, CA, USA). The DNA was denatured by immersing the membranes for $5 \mathrm{~min}$ in $0.2 \mathrm{~N} \mathrm{NaOH}, 0.15 \mathrm{M} \mathrm{NaCl}$, followed by washing with $0.5 \mathrm{M}$ Tris, $3 \mathrm{M} \mathrm{NaCl}, \mathrm{pH}$ 7. DNA was bound to the membranes by ultraviolet cross-linking.
Membranes were prehybridised in hybridisation solution [ $5 \times$ saline sodium citrate (SSC), $1 \%$ blocking reagent (Roche Applied Sciences), $0.1 \% \quad N$-laurylsarcosine, $0.02 \%$ sodium dodecyl sulfate (SDS)] at $65^{\circ}$ for $1 \mathrm{~h}$. Hybridisation was carried out at $65^{\circ} \mathrm{C}$ overnight in fresh hybridisation solution containing the probes, previously denatured by boiling for 5 min and snap cooling on ice.

\section{Survey of bean and soybean crops in northwestern Argentina}

Symptomatic soybean and bean samples were collected from counties in Salta, Jujuy, Catamarca and Tucumán provinces during the 2004, 2005, 2006 and 2007 growing seasons (Figs 1 and S1). Two symptomatic samples of the weed Abutilon theophrasti Medik. were also collected at El Bordo, Gal. Güemes county, Salta province, in 2006. All samples were tested with the general probe under lowstringency conditions. Those samples which yielded a positive reaction were further tested with the specific probes.

\section{Results}

Cloning and sequencing of the DNA-A of isolate A and of the Sida mottle virus-like isolate

The DNA-A components of isolate A and of the SiMoVlike virus were typical of Western Hemisphere, bipartite begomoviruses. The DNA-A of isolate A is 2605-nt long (GenBank accession number EF016486) and that of the SiMoV-like virus is 2632-nt long (accession number FJ538207). The DNA-A of both viruses contains five open-reading frames (ORFs). The positive or virion sense strand contains one ORF corresponding to the $\mathrm{CP}$, predicted to encode 247 aa for isolate A and 251 aa for the SiMoV-like virus. The complementary sense strand of both isolates encodes four ORFs: Rep (348/359 aa), TrAP (129/139 aa), REn (132 aa for both viruses) and AC4 (118/88 aa).

Sequence comparisons indicated that isolate A has the highest nucleotide sequence identity with tomato golden mosaic virus (TGMV, accession number K02029; $78 \%$ identity), and the SiMoV-like with ToYSV (accession number DQ336350; 92\% identity), both viruses originally described in neighbouring Brazil. When the deduced amino acid sequence of individual proteins were compared with those of other begomoviruses, the highest identities were always with TGMV for isolate A and with ToYSV for the SiMoV-like isolate (Table 1). Based on the species demarcation criteria established by the Geminiviridae Study Group of the International Committee for the Taxonomy of Viruses (ICTV) (Fauquet et al., 2008), these results indicate that isolate A represents a distinct species, for which the name Soybean blistering mosaic 


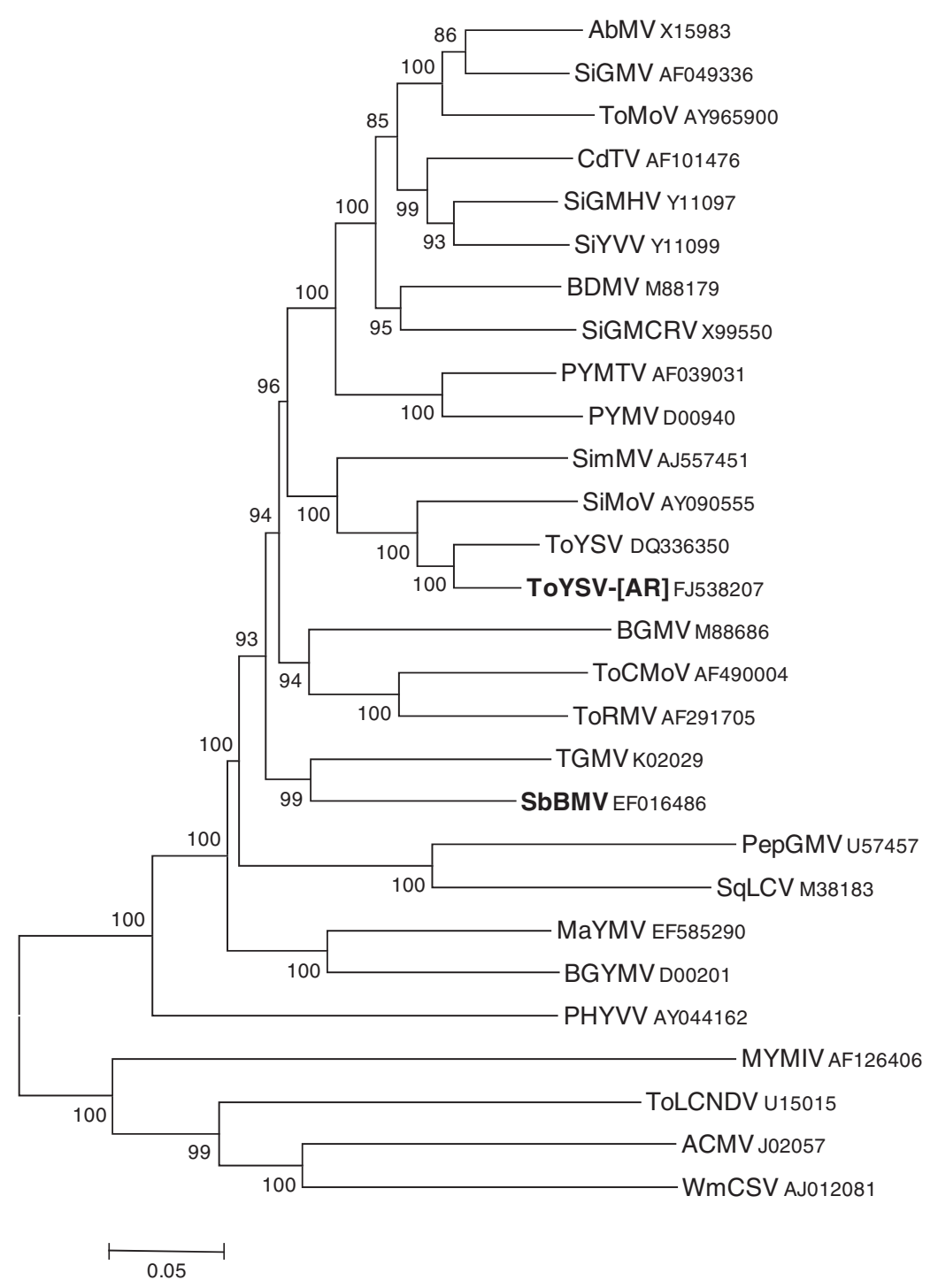

Figure 2 Phylogenetic tree based on the complete DNA-A nucleotide sequences of SbBMV, ToYSV-[AR] and other selected begomoviruses. The tree was constructed using the neighbour-joining method with MEGA 4.0. AbMV, abutilon mosaic virus; ACMV, African cassava mosaic virus; BDMV, bean dwarf mosaic virus; BGMV, bean golden mosaic virus; BGYMV, bean golden yellow mosaic virus; CdTV, Chino del tomate virus; MaYMV, Macroptilium yellow mosaic virus; MYMIV, mungbean yellow mosaic India virus; PepGMV, pepper golden mosaic virus; PHYVV, pepper huasteco yellow vein virus; PYMV, potato yellow mosaic virus; PYMTV, potato yellow mosaic Trinidad virus; SiGMV, Sida golden mosaic virus; SiGMHV, Sida golden mosaic Honduras virus; SiGMCRV, Sida golden mosaic Costa Rica virus; SimMV, Sida micrantha mosaic virus; SiMoV, Sida mottle virus; SiYVV, Sida yellow vein virus; SqLCV, squash leaf curl virus; TGMV, tomato golden mosaic virus; ToCMoV, tomato chlorotic mottle virus; ToLCNDV, tomato leaf curl New Delhi virus; ToMoV, tomato mottle virus; ToRMV, tomato rugose mosaic virus; ToYSV, tomato yellow spot virus; WmCSV, watermelon chlorotic stunt virus.

virus (SbBMV) is proposed, whereas the SiMoV-like virus is actually an isolate of ToYSV, henceforth named ToYSV[AR]. This is the first report of ToYSV naturally infecting beans and also the first time that this virus is found in a country other than Brazil.

The phylogenetic relationship of the DNA-A sequences of SbBMV, ToYSV-[AR] and other selected begomoviruses is shown in Fig. 2. SbBMV was placed together with
TGMV in a monophyletic branch with a 99\% bootstrap confidence value, whereas ToYSV-[AR] clustered, as expected, with the original ToYSV isolate from Brazil.

Development of DNA probes and survey of bean and soybean crops in northwestern Argentina

The general probe detected all begomovirus species tested and did not yield a noticeable hybridisation signal from 


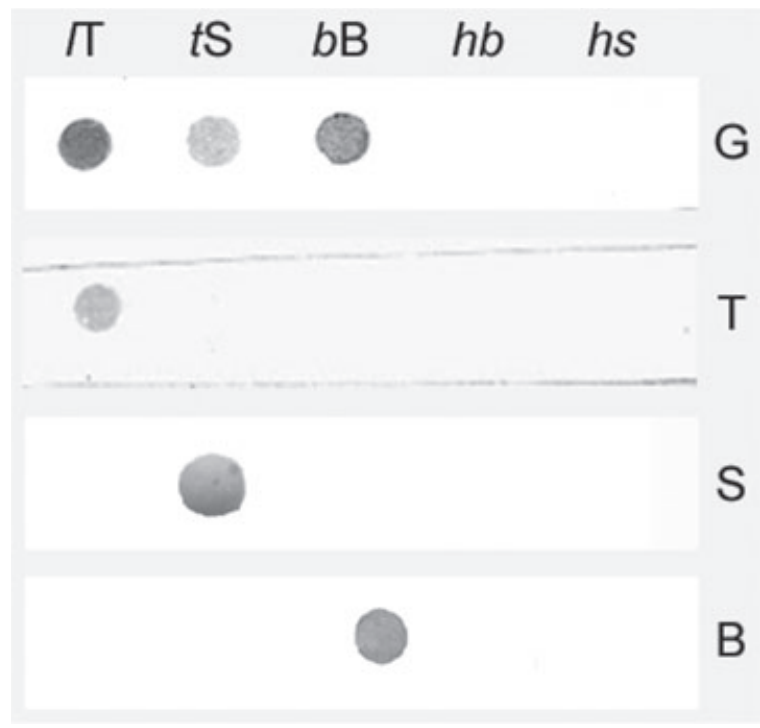

Figure 3 Detection of bean- and soybean-infecting begomoviruses by dot-blot hybridisation with digoxygenin-labelled probes. Lower case, italics letters at the top represent the plant species: (b) bean, (I) Leonurus sibiricus, ( $t$ ) tomato, $(h b)$ healthy bean, (hs) healthy soybean. Upper case letters represent the virus: (B) BGMV, (S) SbBMV, (T) ToYSV. Upper case letters at the right indicate the probe: (G) general probe, (B) BGMV-specific probe, (S) SbBMV-specific probe, (T) ToYSV-specific probe. BGMV, bean golden mosaic virus; SbBMV, soybean blistering mosaic virus; ToYSV, tomato yellow spot virus.

asymptomatic bean or soybean samples (Fig. 3). The specific probes reacted only with their homologous viral targets (Fig. 3).

During the 4-year study (2004-2007), 73 bean and 57 soybean fields were surveyed. Begomoviruses were detected in 49 bean fields (67\% prevalence; Table 2$)$ and in 31 soybean fields (54\% prevalence; Table 3 ).

A total of 486 bean samples showing virus-like symptoms were assessed. Sixty-six percent (320) of these samples tested positive when analysed with the general probe (Table 2). BGMV was the most frequently detected virus: $262(54 \%)$ of the samples were infected with this virus, $58(12 \%)$ with ToYSV and 44 (9\%) with SbBMV. The highest frequency of SbBMV was found in Anta county, Salta province, where 11 of $19(58 \%)$ samples tested positive for this virus in 2005, whereas the highest frequency of ToYSV was found, in the same year, in San Martín county. Mixed infections were observed and found to be more frequent during 2005, when 16 of 118 samples (14\%) were infected with either two or three begomoviruses. ToYSV was also detected in two samples of Abutilon theophrasti, a native species that grows in association with bean and soybean crops.

A total of 389 soybean samples were analysed and 151 $(39 \%)$ tested positive with the general probe (Table 3 ).
Of these 151 samples, $50(33 \%)$ were infected with SbBMV and 27 (18\%) with ToYSV. The highest frequency of begomovirus infection was detected in General San Martín and Oran counties, north of Salta province. Mixed infections with the two viruses were observed in 8 of the 151 samples analysed $(7 \%)$.

\section{Discussion}

In Argentina, the soybean crop was introduced at the end of the nineteenth century, but its production has greatly increased since the 1970s. In 1975, around 400000 ha were sown, and a decade later, the cultivated area reached 3300000 ha, of which 140000 ha in the NW region, which is also the main common bean-producing area of the country. The expansion of the cultivated area with soybean was associated with the emergence of a previously unknown pest in the region: the whitefly B. tabaci. As a result, in the 1980s, Argentina had already lost more than $20 \%$ of its bean crop due to a severe disease commonly known as 'stunting'. It has been determined that this disease involves a begomovirus, but its precise aetiology remains unknown and the viruses involved have not been properly characterised (Morales et al., 1990; Morales, 1994; Morales \& Anderson, 2001). The occurrence of a begomovirus in soybean crops in NW Argentina was first reported in 1997 (Sakai et al., 1997). Further evidence based on molecular characterisation showed that at least three begomoviruses infect soybean and bean crops in NW Argentina: BGMV, detected only in bean crops; an isolate with high identity at the $\mathrm{N}$-terminal region of the capsid protein with SiMoV, previously detected in Brazil; and a possible new viral species (isolate A) (Rodríguez-Pardina et al., 2006).

In this study, the molecular characterisation of the SiMoV-like virus and of isolate A was carried out. The results indicated that isolate A represents a distinct species in the genus Begomovirus, for which the name SbBMV is proposed. This virus was found in both soybean and bean crops and was also detected in tomato (RodríguezPardina et al., 2006) and in Leonurus sibiricus L., a weed that grows in association with bean and soybean fields of the NW region (P. Rodríguez-Pardina, unpublished results). On the other hand, the SiMoV-like virus has the highest nucleotide sequence identity (92\%) with ToYSV, a begomovirus previously described infecting tomatoes in Brazil, and is phylogenetically closer to viruses from Sida spp. than from tomato (Andrade et al., 2006).

A general begomovirus probe and three speciesspecific DNA probes were developed for the detection of BGMV, SbBMV and ToYSV in field-collected plant samples. These probes were used to test symptomatic bean and soybean samples during four consecutive growing 
Table 2 Detection of begomoviruses in bean crops in Northwestern Argentina from the 2004 to the 2007 growing seasons by molecular hybridisation using general ('begomovirus') and virus-specific ('BGMV', 'SbBMV' and 'ToYSV') probes

\begin{tabular}{|c|c|c|c|c|c|c|c|}
\hline Year & Province & County & Begomovirus, Total (\%) & BGMV, Total (\%) & SbBMV, Total (\%) & ToYSV, Total (\%) & Unidentified ${ }^{a}$, Total $(\%$ \\
\hline \multirow[t]{8}{*}{2004} & \multirow[t]{4}{*}{ Salta } & Cerrillos & $1 / 14(7.2)$ & $1 / 1(100)$ & $0 / 1(0)$ & $0 / 1(0)$ & $0 / 1(0)$ \\
\hline & & Gal. San Martín & $5 / 24(21)$ & $0 / 5(0)$ & $0 / 5(0)$ & $4 / 5(80)$ & $1 / 5(20)$ \\
\hline & & Orán & $8 / 17(47)$ & $1 / 8(12.5)$ & $0 / 8(0)$ & $1 / 8(12.5)$ & $6 / 8(75)$ \\
\hline & & R. de la Frontera & $0 / 1(0)$ & - & - & - & - \\
\hline & \multirow[t]{3}{*}{ Jujuy } & El Carmen & $3 / 26(11.5)$ & $0 / 3(0)$ & $0 / 3(0)$ & $1 / 3(33.3)$ & $2 / 3(66.7)$ \\
\hline & & \multirow[t]{2}{*}{ Sta. Barbara } & $2 / 2(100)$ & $2 / 2(100)$ & $0 / 2(0)$ & $0 / 2(0)$ & $0 / 2(0)$ \\
\hline & & & $1 / 3(33.3)$ & $1 / 1(100)$ & $0 / 1(0)$ & $0 / 1(0)$ & $0 / 1(0)$ \\
\hline & Tucumán & Trancas & $0 / 1(0)$ & - & - & - & - \\
\hline \multirow[t]{8}{*}{2005} & \multirow[t]{8}{*}{ Salta } & Anta & $19 / 23(83)$ & $3 / 19(16)$ & $11 / 19(58)$ & $0 / 19(0)$ & $5 / 19(26)$ \\
\hline & & \multirow[t]{3}{*}{ Gal. San Martín } & $18 / 21(86)$ & $15 / 18(83)$ & $1 / 18(5.5)$ & $5 / 18(28)$ & $0 / 18(0)$ \\
\hline & & & $37 / 53(70)$ & $25 / 37(67.5)$ & $3 / 37(8)$ & $5 / 37(13.5)$ & $4 / 37(11)$ \\
\hline & & & 16/18 (89) & $16 / 16(100)$ & $0 / 16(0)$ & $0 / 16(0)$ & $0 / 16(0)$ \\
\hline & & La Candelaria & $9 / 39(23)$ & $3 / 9(30)$ & $0 / 9(0)$ & $0 / 9(0)$ & $6 / 9(70)$ \\
\hline & & Metán & $0 / 21(0)$ & - & - & - & - \\
\hline & & Orán & $5 / 6(83)$ & $5 / 5(100)$ & $0 / 5(0)$ & $4 / 5(80)$ & $0 / 5(0)$ \\
\hline & & R. de la Frontera & $2 / 4(50)$ & $2 / 2(100)$ & $0 / 2(0)$ & $0 / 2(0)$ & $0 / 2(0)$ \\
\hline \multirow[t]{9}{*}{2006} & \multirow[t]{7}{*}{ Salta } & \multirow[t]{2}{*}{ Gal. San Martín } & $26 / 30(87)$ & $12 / 26(46)$ & $0 / 26(0)$ & $2 / 16(8)$ & $12 / 26(46)$ \\
\hline & & & $12 / 17(70)$ & $10 / 12(83)$ & $0 / 12(0)$ & $0 / 12(0)$ & $2 / 12(17)$ \\
\hline & & \multirow[t]{3}{*}{ Gal. Güemes } & $8 / 9(89)$ & $6 / 8(75)$ & $3 / 8(37.5)$ & $2 / 8(25)$ & $0 / 8(0)$ \\
\hline & & & $26 / 28(93)$ & $16 / 26(61.5)$ & $0 / 26(0)$ & $0 / 26(0)$ & $10 / 26(38.5)$ \\
\hline & & & $16 / 16(100)$ & $13 / 16(81)$ & $1 / 16(6.2)$ & $4 / 16(25)$ & $0 / 16(0)$ \\
\hline & & \multirow[t]{2}{*}{ Orán } & 16/19 (84) & $7 / 16(44)$ & $0 / 16(0)$ & $2 / 16(12.5)$ & $7 / 16(43.7)$ \\
\hline & & & $1 / 6(16.7)$ & $1 / 1(100)$ & $0 / 1(0)$ & $0 / 1(0)$ & $0 / 1(0)$ \\
\hline & \multirow[t]{2}{*}{ Jujuy } & Ledesma & $8 / 13(61.5)$ & $0 / 8(0)$ & $0 / 8(0)$ & $0 / 8(0)$ & $8 / 8(100)$ \\
\hline & & San Pedro & $11 / 11(100)$ & $2 / 11(18)$ & $0 / 11(0)$ & $0 / 11(0)$ & $9 / 11(82)$ \\
\hline \multirow[t]{8}{*}{2007} & \multirow[t]{5}{*}{ Salta } & Capital & $10 / 10(100)$ & $5 / 10(50)$ & $2 / 10(20)$ & $1 / 10(10)$ & $2 / 10(20)$ \\
\hline & & \multirow[t]{2}{*}{ Gal. San Martín } & $18 / 34(53)$ & $13 / 18(72)$ & $5 / 18(28)$ & $3 / 18(16)$ & $0 / 18(0)$ \\
\hline & & & $10 / 14(71.5)$ & $6 / 10(60)$ & $1 / 10(10)$ & $0 / 10(0)$ & $3 / 10(30)$ \\
\hline & & Metán & $9 / 11(82)$ & $3 / 9(33)$ & $0 / 9(0)$ & $1 / 9(11)$ & $5 / 9(55.5)$ \\
\hline & & Orán & $20 / 42(47)$ & $10 / 20(50)$ & $2 / 20(10)$ & $1 / 20(5)$ & $7 / 20(35)$ \\
\hline & \multirow[t]{3}{*}{ Jujuy } & Sta. Barbara & $6 / 24(25)$ & $1 / 6(17)$ & $0 / 6(0)$ & $0 / 6(0)$ & $5 / 6(83)$ \\
\hline & & \multirow[t]{2}{*}{ San Pedro } & $4 / 8(50)$ & $0 / 4(0)$ & $0 / 4(0)$ & $1 / 4(25)$ & $3 / 4(75)$ \\
\hline & & & $5 / 7(71.5)$ & $3 / 5(60)$ & $0 / 5(0)$ & $0 / 5(0)$ & $2 / 5(40)$ \\
\hline
\end{tabular}

BGMV, bean golden mosaic virus; SbBMV, soybean blistering mosaic virus; ToYSV, tomato yellow spot virus.

asamples that yielded a positive result with the general probe but that were negative with all three species-specific probes and which are therefore concluded to be infected with a distinct begomovirus.

seasons. Sixty-six percent of bean and $39 \%$ of soybean samples tested positive when analysed with the general probe. The highest prevalence of begomoviruses, up to $100 \%$, occurred during the 2006 and 2007 growing seasons. BGMV was the most frequent virus in bean crops but was not detected in soybean crops. Interestingly, a high percentage of symptomatic bean and soybean samples that tested positive when analysed with the general probe did not react with any of the three specific probes, so the presence of other uncharacterised begomoviruses is suspected. The lack of begomovirus detection in samples displaying virus-like symptoms might be due to the presence of other viruses such as bean common mosaic virus, cucumber mosaic virus, cowpea mild mottle virus or alfalfa mosaic virus, all of which have been previously reported to infect bean and soybean crops in Argentina (Laguna et al., 1988, 2006; Rodríguez-Pardina et al., 2004).

The role of weeds in the epidemiology of begomoviruses is unclear. Some studies suggest that weeds are not important as reservoirs of bean-infecting begomoviruses (Gilbertson et al., 1991; Frischmuth et al., 1997). However, our study raises the possibility that weeds such as $A$. theophrasti, which are natural hosts of bean- and soybean-infecting begomoviruses, could serve as reservoir hosts and primary inoculum sources of these viruses. Further epidemiological studies are necessary to test this hypothesis. 
Table 3 Detection of begomoviruses in soybean crops in Northwestern Argentina from the 2004 to the 2007 growing seasons by molecular hybridisation using general ('begomovirus') and virus-specific ('BGMV', 'SbBMV' and 'ToYSV') probes

\begin{tabular}{|c|c|c|c|c|c|c|c|}
\hline Year & Province & County & Begomovirus, Total (\%) & BGMV, Total (\%) & SbBMV, Total (\%) & ToYSV, Total (\%) & Unidentified $^{a}$ \\
\hline \multirow[t]{2}{*}{2004} & \multirow[t]{2}{*}{ Tucumán } & Cruz Alta & $0 / 5(0)$ & - & - & - & - \\
\hline & & La Cocha & $16 / 32(50)$ & $0 / 16(0)$ & $3 / 16(18.7)$ & $3 / 16(18.7)$ & $10 / 16(62.5)$ \\
\hline \multirow[t]{12}{*}{2005} & \multirow[t]{6}{*}{ Tucumán } & Buruyacu & $4 / 8(50)$ & $0 / 4(0)$ & $0 / 4(0)$ & $4 / 4(100)$ & $0 / 4(0)$ \\
\hline & & Chicligasta & $0 / 1(0)$ & - & - & - & - \\
\hline & & La Cocha & $1 / 18(5.5)$ & $0 / 1(0)$ & $0 / 1(0)$ & $1 / 1(100)$ & $0 / 1(0)$ \\
\hline & & Granero & $5 / 12(42)$ & $0 / 5(0)$ & $0 / 5(0)$ & $2 / 5(40)$ & $3 / 5(60)$ \\
\hline & & & & & $0 / 1(0)$ & & \\
\hline & & Leales & $1 / 1(100)$ & $0 / 1(0)$ & & $1 / 1(100)$ & $0 / 1(0)$ \\
\hline & \multirow[t]{6}{*}{ Salta } & Gal. San Martín & $42 / 79(53.7)$ & $0 / 42(0)$ & $2 / 42(4.7)$ & $3 / 42(7.1)$ & $37 / 42(88)$ \\
\hline & & Metán & $2 / 11(18)$ & $0 / 2(0)$ & $1 / 2(50)$ & $1 / 2(50)$ & $0 / 2(0)$ \\
\hline & & & & & $0 / 5(0)$ & & \\
\hline & & Orán & $5 / 13(38.5)$ & $0 / 5(0)$ & & $0 / 5(0)$ & $5 / 5(100)$ \\
\hline & & & & $0 / 1(0)$ & & & \\
\hline & & R. de la Frontera & $1 / 1(100)$ & & $0 / 1(0)$ & $0 / 1(0)$ & $1 / 1(100)$ \\
\hline \multirow[t]{2}{*}{2006} & \multirow[t]{2}{*}{ Salta } & Gal. San Martín & $24 / 41(58.5)$ & $0 / 24(0)$ & $11 / 24(46)$ & $10 / 24(42)$ & $2 / 24(8.3)$ \\
\hline & & Orán & $8 / 14(57)$ & $0 / 8(0)$ & $6 / 8(83)$ & $0 / 8(0)$ & $2 / 8(25)$ \\
\hline \multirow[t]{11}{*}{2007} & \multirow[t]{7}{*}{ Tucumán } & Alberdi & $2 / 2(100)$ & $0 / 2(0)$ & $1 / 2(50)$ & $0 / 2(0)$ & $1 / 2(50)$ \\
\hline & & Buruyacu & $3 / 14(21.4)$ & $0 / 3(0)$ & $2 / 3(66.7)$ & $0 / 3(0)$ & 1/3 (33.3) \\
\hline & & Cruz Alta & $0 / 3(0)$ & - & - & - & - \\
\hline & & Granero & $1 / 4(25)$ & $0 / 1(0)$ & $0 / 1(0)$ & $1 / 1(100)$ & $0 / 1(0)$ \\
\hline & & La Cocha & $1 / 4(25)$ & $0 / 1(0)$ & $0 / 1(0)$ & $0 / 1(0)$ & $1 / 1(100)$ \\
\hline & & & & & $1 / 2(50)$ & & \\
\hline & & Lules & $2 / 6(33)$ & $0 / 2(0)$ & & $1 / 2(50)$ & $0 / 2(0)$ \\
\hline & \multirow[t]{4}{*}{ Salta } & Gal. San Martín & $23 / 28(82)$ & $0 / 23(0)$ & $15 / 23(65)$ & $0 / 23(0)$ & $8 / 23(34)$ \\
\hline & & Metán & $1 / 5(20)$ & $0 / 1(0)$ & $0 / 1(0)$ & $0 / 1(0)$ & $1 / 1(100)$ \\
\hline & & Orán & $9 / 19(47)$ & $0 / 9(0)$ & $8 / 9$ (89) & $0 / 9(0)$ & $1 / 9(11)$ \\
\hline & & R. de la Frontera & $0 / 1(0)$ & - & - & - & - \\
\hline
\end{tabular}

BGMV, bean golden mosaic virus; SbBMV, soybean blistering mosaic virus; ToYSV, tomato yellow spot virus.

asamples that yielded a positive result with the general probe but that were negative with all three species-specific probes and which are therefore concluded to be infected with a distinct begomovirus.

\section{Acknowledgements}

This work was performed within the scope of a Brazil-Argentina bilateral agreement (CAPES-SECyT 072/04) and was partially supported by CNPq grant 400750/2004-0 to F. M. Z. P. E. R. P. was financially supported by a CAPES fellowship. The authors wish to thank Dr Jesús Navas-Castillo for critical reading of the article.

\section{Supporting Information}

Additional Supporting Information may be found in the online version of this article:

Figure S1 (a) Soybean sample infected with SbBMV. (b) Bean sample infected with ToYSV. (c) Bean sample coinfected with ToYSV and SbBMV. Infections were confirmed by dot-blot hybridization with virus-specific probes under high stringency conditions. Please note: Wiley-Blackwell are not responsible for the content or functionality of any supporting materials supplied by the authors. Any queries (other than missing material) should be directed to the corresponding author for the article.

\section{References}

Altschul S.F., Gish W., Miller W., Myers E.W., Lipman D.J. (1990) Basic local alignment search tool. Journal of Molecular Biology, 215, 403-410.

Andrade E.C., Manhani G.G., Alfenas P.F., Calegario R.F., Fontes E.P.B., Zerbini F.M. (2006) Tomato yellow spot virus, a tomato-infecting begomovirus from Brazil with a closer relationship to viruses from Sida sp., forms pseudorecombinants with begomoviruses from tomato but not from Sida. Journal of General Virology, 87, 3687-3696.

Brown J.K., Ostrow K.M., Idris A.M., Stenger D.C. (1999) Biotic, molecular, and phylogenetic characterization of bean calico mosaic virus, a distinct Begomovirus species with affiliation in the squash leaf curl virus cluster.

Phytopathology, 89, 273-280.

Costa A.S. (1975) Increase in the populational density of Bemisia tabaci, a threat to widespread virus infection of legume crops in Brazil. In Tropical Diseases of Legumes, p. 171. Eds J. Bird and K. Maramorosch. New York: Academic Press. 
Dellaporta S.L., Wood J., Hicks J.B. (1983) A plant DNA minipreparation: version II. Plant Molecular Biology Reporter, 1, 19-21.

Doyle J.J., Doyle J.L. (1987) A rapid DNA isolation procedure for small amounts of fresh leaf tissue. Phytochemical Bulletin, 19, 11-15.

Fauquet C.M., Briddon R.W., Brown J.K., Moriones E., Stanley J., Zerbini F.M., Zhou X. (2008) Geminivirus strain demarcation and nomenclature. Archives of Virology, 153, 783-821.

Fernandes F.R., Cruz A.R.R., Faria J.C., Zerbini F.M., Aragão F.J.L. (2009) Three distinct begomoviruses associated with soybean in central Brazil. Archives of Virology, 154, 1567-1570.

Frischmuth T., Engel M., Lauster S., Jeske H. (1997) Nucleotide sequence evidence for the occurrence of three distinct whitefly-transmitted, Sida-infecting bipartite geminiviruses in Central America. Journal of General Virology, 78, 2675-2682.

Garrido-Ramirez E.R., Sudarshana M., Gilbertson R.L. (2000) Bean golden yellow mosaic virus from Chiapas, Mexico: characterization, pseudorecombination with other bean-infecting geminiviruses and germ plasm screening. Phytopathology, 90, 1224-1232.

Gilbertson R.L., Faria J.C., Ahlquist P., Maxwell D.P. (1993) Genetic diversity in geminiviruses causing bean golden mosaic disease: the nucleotide sequence of the infectious cloned DNA components of a Brazilian isolate of bean golden mosaic geminivirus. Phytopathology, 83, 709-715.

Gilbertson R.L., Hidayat S.H., Martinez R.T., Leong S.A., Faria J.C., Morales F.J., Maxwell D.P. (1991)

Diferentiation of bean-infecting geminiviruses by nucleic acid hybridization probes and aspects of bean golden mosaic in Brazil. Plant Disease, 75, 336-342.

Idris A.M., Hiebert E., Bird J., Brown J.K. (2003) Two newly described begomoviruses of Macroptilium lathyroides and common bean. Phytopathology, 93, 774-783.

Inoue-Nagata A.K., Albuquerque L.C., Rocha W.B., Nagata T. (2004) A simple method for cloning the complete begomovirus genome using the bacteriophage phi 29 DNA polymerase. Journal of Virological Methods, 116, 209-211.

Laguna I.G., Arneodo J.D., Rodríguez-Pardina P.E., Fiorona M. (2006) Cowpea mild mottle virus infecting soybean crops in Northewestern Argentina. Fitopatologia Brasileira, 31, 283.

Laguna I.G., Rodríguez-Pardina P.E., Truol G. (1988) Enfermedades de etiología virosa en cultivos de soja (Glycine max (L.) Merr.) en la Argentina. Fitopatologia Brasileira, 13, 192-198.

Mello R.N., Cotrim M.A.A., Lopes E.F., Moreira A.G., Contin F.S., Fontes E.P.B., Almeida A.M.R., Zerbini F.M. (2002) Survey of begomoviruses associated with soybean and identification of Sida mottle virus (SiMoV) infecting this crop in Brazil. Virus Reviews and Research, 7, 157.
Mendez-Lozano J., Quintero-Zamora E., Barbosa-Jasso M.P., Leyva-Lopez N.E., Garzon-Tiznado J.A., Arguello-Astorga G.R. (2006) A Begomovirus associated with leaf curling and chlorosis of soybean in Sinaloa, Mexico is related to Pepper golden mosaic virus. Plant Disease, 90, 109-109.

Morales F., Niessen A., Ramirez B., Castaño M. (1990) Isolation and partial characterization of a geminivirus causing bean dwarf mosaic. Phytopathology, 80, 96-101.

Morales F.J. (1994) Situación del mosaico dorado en la América del Sur: Brasil. In Bean Golden Mosaic: Research Advances, pp. 90-95. Ed F.J. Morales. Cali, Colombia: CIAT.

Morales F.J., Anderson P.K. (2001) The emergence and dissemination of whitefly-transmitted geminiviruses in Latin America. Archives of Virology, 146, 415-441.

Morales F.J., Rivera Bustamante R., Salinas Perez R., Torres-Pacheco I., Plaza D., Avilés Baeza W., Ramírez-Jaramillo W. (2005) Whiteflies as vectors of viruses in legume and vegetable mixed cropping systems in the tropical lowlands of Central America, Mexico and the Caribbean. In Whitefly and Whitefly-Borne Viruses in the Tropics. Building a Knowledge Base for Global Action, p. 351. Eds P.K. Anderson and F.J. Morales. Cali, Colombia: CIAT.

Navas-Castillo J., Sanchez-Campos S., Diaz J.A., Saez-Alonso E., Moriones E. (1999) Tomato yellow leaf curl virus-Is causes a novel disease of common bean and severe epidemics in tomato in Spain. Plant Disease, 83, 29-32.

Rodríguez-Pardina P.E., Zerbini F.M., Ducasse D.A. (2004) Survey and preliminary identification of begomoviruses infecting soybean and bean in Northwestern Argentina. In 4th International Geminivirus Symposium - Program and Abstracts, pp. P3-P15.

Rodríguez-Pardina P.E., Zerbini F.M., Ducasse D.A. (2006) Genetic diversity of begomoviruses infecting soybean, bean and associated weeds in Northwestern Argentina. Fitopatologia Brasileira, 31, 342-348.

Rojas M.R., Gilbertson R.L., Russell D.R., Maxwell D.P. (1993) Use of degenerate primers in the polymerase chain reaction to detect whitefly-transmitted geminiviruses. Plant Disease, 77, 340-347.

Rojas M.R., Hagen C., Lucas W.J., Gilbertson R.L. (2005) Exploiting chinks in the plant's armor: evolution and emergence of geminiviruses. Annual Review of Phytopathology, 43, 361-394.

Sakai J., Rodríguez-Pardina P.E., Onuki M., Usugi T., Shohara K., Hanada K. (1997) Nucleotide sequence of a Geminivirus isolate detected from soybean showing yellow and rogues symptoms in Argentina. Annals of the Phytopathological Society of Japan, 63, 270.

Salati R., Nahkla M.K., Rojas M.R., Guzman P., Jaquez J., Maxwell D.P., Gilbertson R.L. (2002) Tomato yellow leaf 
curl virus in the Dominican Republic: characterization of an infectious clone, virus monitoring in whiteflies, and identification of reservoir hosts. Phytopathology, 92, 487-496.

Singh S.P. (1999) Production and utilization. In Common Bean Improvement in the Twenty-First Century (Developments in Plant Breeding). Ed S.P. Singh. Wageningen, The Netherlands: Kluwer Academic Press.
Tamura K., Dudley J., Nei M., Kumar S. (2007) MEGA4 Molecular Evolutionary Genetics Analysis (MEGA) software version 4.0. Molecular Biology and Evolution, 24, 1596-1599.

Vila-Aiub M.M., Vidal R.A., Balbi M.C., Gundel P.E., Trucco F., Ghersa C.M. (2008) Glyphosate-resistant weeds of South American cropping systems: an overview. Pest Management Science, 64, 366-371. 